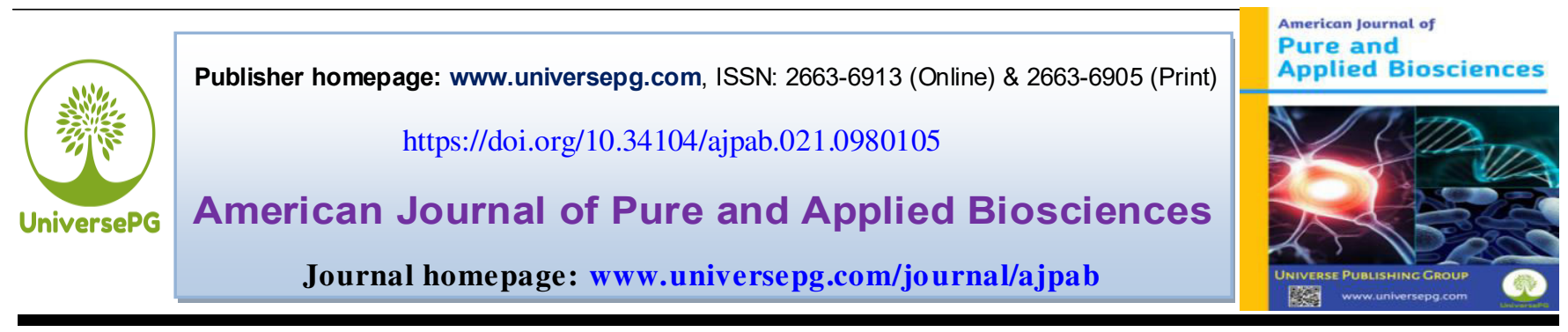

\title{
Response of Different Doses of Nitrogen Fertilizer on Growth and Yield of KangKong (Ipomoea reptans poir)
}

\author{
Shaila Sharmin ${ }^{1}$, Rexona Parvin ${ }^{2}$ and Umme Habiba ${ }^{2}$ \\ ${ }^{1 \& 2}$ College of Agricultural Sciences, International University of Business Agriculture and Technology (IUBAT), Dhaka, \\ Bangladesh. \\ *Correspondence: shaila.sharmin@iubat.edu (Dr. Shaila Sharmin, Associate Professor, College of Agricultural Sciences, \\ IUB AT, Dhaka, Bangladesh).
}

\section{ABSTRACT}

The experiment was conducted at the Agricultural Research Field of International University of Business Agriculture and Technology, Dhaka during the period from August to October 2020 to investigate the response of different doses of nitrogen fertilizer on growth and yield of Kangkong (Ipomoea reptans poir). The experiment consisted of four nitrogen fertilizer levels viz. $\mathrm{T}_{0}$ : no fertilizer, $\mathrm{T}_{1}: 60 \mathrm{~kg}$ nitrogen fertilizer, $\mathrm{T}_{2}: 80$ $\mathrm{kg}$ nitrogen fertilizer and $\mathrm{T}_{3}: 100 \mathrm{~kg}$ nitrogen fertilizer per hectare. The result revealed that plant height, number of leaves per plant, number of branches per plant, fresh weight per plant, dry weight per plant, root length per plant, fresh weight of root per plant, dry weight of root per plant, yield per plot and yield per hectare grown under different doses of nitrogen fertilizer viz. control $\left(T_{0}\right), 60 \mathrm{~kg} \mathrm{~N}$ per hectare $\left(\mathrm{T}_{1}\right), 80 \mathrm{~kg} \mathrm{~N}$ per hectare $\left(\mathrm{T}_{2}\right)$, showed significant reduction than those grown in $100 \mathrm{~kg} \mathrm{~N}$ per hectare $\left(\mathrm{T}_{3}\right)$. The experiment was conducted following Randomized Complete Block Design (RCBD) with four replications. The application of different doses of nitrogen significantly influences the growth and yield of Kangkong. The maximum plant height, number of leaves, number of branches, fresh weight per plant, root length was obtained from $\mathrm{T}_{3}$ treatment while the minimum was found from the control treatment $\left(\mathrm{T}_{0}\right)$ at 60 days after sowing. The highest yield (17.87 $\left.\mathrm{t} / \mathrm{ha}\right)$ was performed from the treatment $\mathrm{T}_{3}$ and the lowest yield $(11.83 \mathrm{t} / \mathrm{ha})$ was obtained from the control treatment where no nitrogen was used.

Keywords: Kangkong, Fertilizer, Nitrogen level, Management, Growth, Response, Yield and Production.

\section{INTRODUCTION:}

Kangkong (Ipomoea reptans poir) a leafy vegetable crop is grown in Bangladesh belongs to the family Convolvulaceae. The crop is also known as Gimakalmi, swamp cabbage, water convolvulus, water spinach, etc. It is an important leafy vegetable of the SouthEast-Asia and is widely grown throughout the South East Asian countries, Australia and some parts of Africa (Hossain \& Siddique, 1982). Leafy vegetables UniversePG I www.universepg.com such as Gimakalmi, spinach, Indian spinach and amaranth are commonly close to the "spinach group" of vegetables (Shinohara, 1980). It was developed from an introduced strain of Kangkong brought from Taiwan by the Horticulture Research centre, BARI, Gazipur (Rashid et al., 1985). Spinach is usually recommended for the enrichment of the human diet, but unfortunately, the crop cannot be grown during the summer and rainy season in Bangladesh, while a 
serious scarcity of vegetables prevails during that time. The development of Gimakalmi is a good achievement since this is suitable for growing both in summer and the rainy season (Shinohara, 1978, 1980). Although similar, the aquatic type of local Kolmi is naturally grown in ponds or marshy land of Bangladesh, Gimakalmi is of special significance because it grows in upland soil with an appreciable yield potential of foliage. From the nutritional point of view, Kangkong is a very important leafy vegetable, it is nutritionally rich in vitamins, minerals, calories etc. and especially it is an excellent source of Vitamin A. Leafy vegetable of $100 \mathrm{~g}$ of its edible portion contains $87.6 \mathrm{~g}$ water, 1.1 $\mathrm{g}$ minerals, $0.1 \mathrm{~g}$ fat, $9.4 \mathrm{~g}$ carbohydrates, $107 \mathrm{mg}$ calcium, $3.9 \mathrm{mg}$ iron, 10740 microgram carotene, 0.14 $\mathrm{mg}$ vita-min B1, $0.40 \mathrm{mg}$ vitamin $\mathrm{B} 2,42 \mathrm{mg}$ vitamin C, $1.8 \mathrm{~g}$ protein and 46 kilocalories. Since it requires low input, easy to grow, and is suitable for growing in summer, its cultivation should be increased. Application of fertilizer in judicious dose is one of the most important aspects of crop production. It is known that nitrogen has a positive role in improving the vegetative growth of plants. Among the nutrient required by plants in a large amount, nitrogen is the most essential and at the same time, one of the most important growth factors in controlling yield and quality of most vegetable crop (Karim et al., 2021; Qamar et al., 2018).

Nitrogen fertilizer plays an important role in agricultural production and has the strongest effect on increasing agricultural production and income. Nitrogen is an element that has a significant role in photosynthesis which involves the opening of the stomata. The stomata vent will decrease following the nitrogen deficit which then will decrease the transpiration rate (stiller et al., 2003). Early and rapid vegetative growth which is required for successful production of Gimakalmi noticeably responds well by the nitrogenous fertilizers added to the soil. However, the optimum quantity of this fertilizer varies depending on the agro-climatic situation. As several harvests are done from a single plant so the use of nitrogenous fertilizer for the production of Gimakalmi is important. In Bangladesh, urea is mostly used as the source of nitrogen, and split application of this fertilizer is commonly practiced (Hossain, 1990). The harvest interval can also influence the yield of Gimakalmi.

UniversePG I www.universepg.com
Harvesting of the crop on the $30^{\text {th }}$ day after sowing is recommended to start (Anonymous, 1983). The edible portion of this crop is leafy vegetables. Naturally hard fibrous shoots are unfit for consumption. Moreover, harvest interval is correlated with the application of nitrogen. So, at the time of harvesting, two things are to be taken into consideration simultaneously-good quality and reasonable yield. Li et al. (2019) showed that more nitrogen application would affect the growth of the plant and also, less nitrogen will also affect the plants leaving them under nitrogen stress. Considering the above factors, the present experiment was undertaken to study the response of different doses of nitrogen on the growth and yield of kangkong. This research may help our vegetable growers who are involved in the cultivation of vegetables in Bangladesh.

\section{MATERIALS AND METHODS:}

Experimental site and Location - The field experiment was carried at the Agriculture Research Field of International University of Business Agriculture and Technology, Dhaka 1230, Bangladesh during the period from August 2020 to October 2020 in the Kharif season. Geographically the experimental field is located at $23.8883^{\circ}$ Latitude and $90.3907^{\circ}$ E longitudes with an elevation of 4 meters from the sea level. The climate of the area is characterized by high temperature and high rainfall with an annual rainfall of $119-145 \mathrm{~cm}$ from July to September and medium rainfall during October. The texture of the soil was sandy loam and the $\mathrm{pH}$ was 6.5 .

Test crop and intercultural operations - In this research work, Kangkong seed BARI Gimakalmi-1@ $10 \mathrm{~kg} / \mathrm{ha}$ was used as planting material. Seeds were sown on 14 August 2020. Two seeds were sown directly in each planting hole at one $\mathrm{cm}$ depth and covered with a thin layer of soil. The rows were placed $30 \mathrm{~cm}$ apart while the spacing between the plants in a row was $20 \mathrm{~cm}$. Thinning was done seven days after emergence and only one seedling was allowed to grow in each location. At the time of irrigation, care was taken so that no water logging condition occurred at any place in the experimental area. The plants were kept under careful observation. Weeding was done when necessary. No insecticides or fungicides were applied since there was no problem of insect or disease infestation. 
Experimental design and layout - The experiment was laid out following Randomized Complete Block Design (RCBD) with four replications. The total area of the experimental plot was $10 \mathrm{~m} \times 3 \mathrm{~m}=30 \mathrm{~m}^{2}$ which was divided into four equal blocks. Each block was divided into 4 plots where 4 treatments were allotted at random. Thus, there were 16-unit plots altogether in the experiment. The size of each plot was $1 \mathrm{~m} \times 1 \mathrm{~m}$. The distance between two blocks and two plots was kept at $0.5 \mathrm{~m}$. and $0.25 \mathrm{~m}$. respectively. A layout of the experiment has been shown in Fig 1.
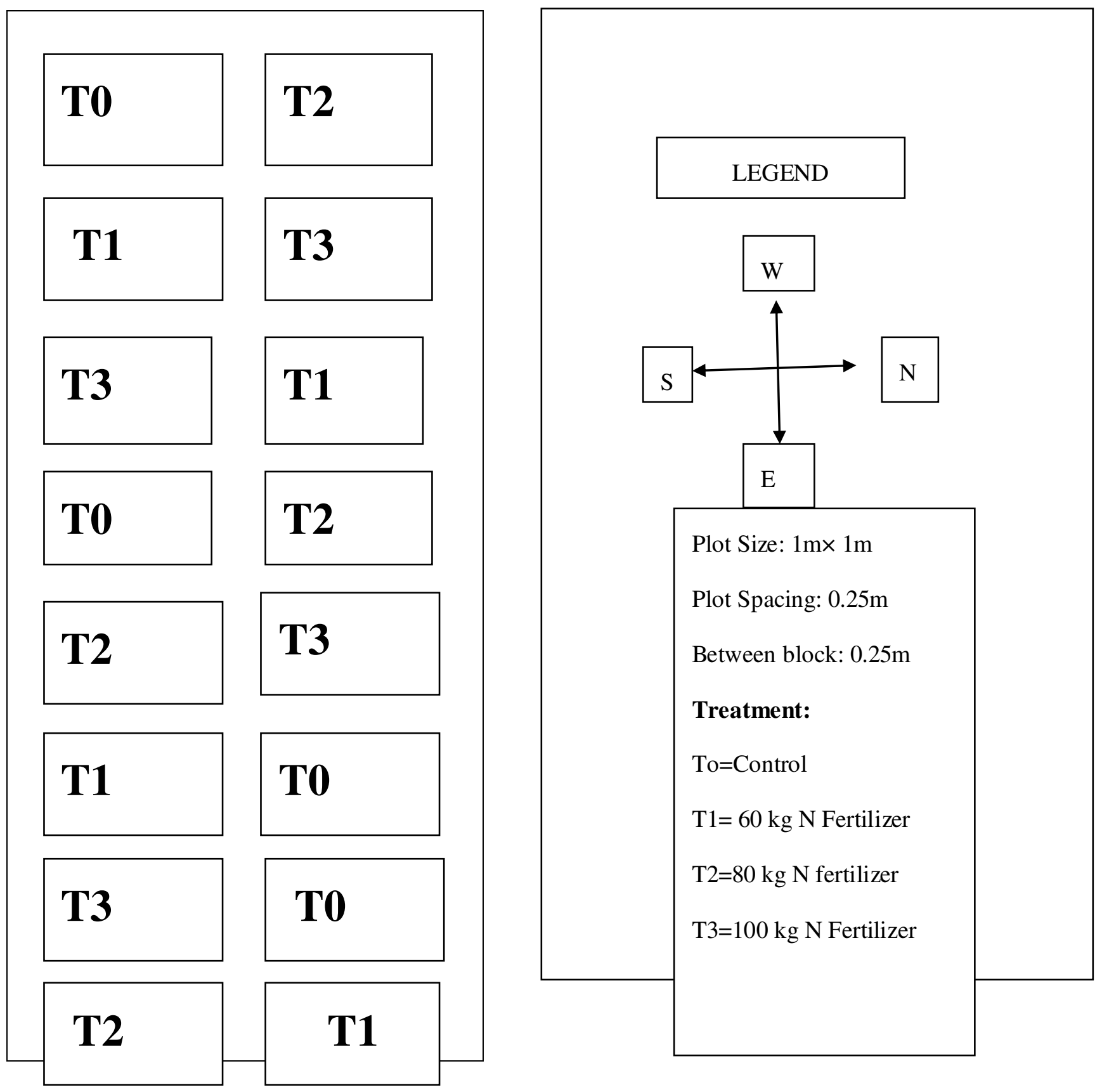

Fig 1: Field layout of the single factor experiment in the Randomized Complete Block Design (RCBD).

Application of manure and fertilizers - Manure and fertilizers such as Cow dung, Triple Super Phosphate (TSP), and Muriate of Potash (MOP) were applied in the experimental field as per the recommendation of BARC, 2012. Four nitrogen levels viz., O, 60; 80 and UniversePG I www.universepg.com
$100 \mathrm{~kg} \mathrm{~N}$ ha-I were included in the experiment like to $=$ Control, $T_{1}=60 \mathrm{~kg} \mathrm{~N}$ Fertilizer, $\mathrm{T}_{2}=80 \mathrm{~kg} \mathrm{~N}$ fer tilizer, $\mathrm{T}_{3}=100 \mathrm{~kg} \mathrm{~N}$ Fertilizer. Fertilizers applied in the plots as recommended for high yield goal and very low soil fertility status as described in Fertilizer Re- 
commendation Guide (FRG, 2012). The entire amount of cow dung, triple superphosphate and muriate of potash were applied during the final land preparation. The whole amount of urea was applied in equal 3 splits as per treatment in the plot after sowing. The first harvest was done from all plots 35 days after sowing. The plants were cut at a height of 7-8 cm from the ground level and data were recorded on different characters. The crop was allowed to grow and harvests were done 60 days after sowing respectively.

Data Collection and Statistical analysis - Ten plants were randomly selected from each unit plot for the collection of data. Data were collected in respect of the characters like Plant height $(\mathrm{cm})$ Number of branches per plant, Number of leaves per plant, Fresh weight of plant (gm) Dry weight of plant (g), Root length $(\mathrm{cm})$ Fresh and Dry weight of root (g) Yield per plot (g) Yield per ton/hac. The recorded data on different characters were statistically analyzed to find out the significance of difference among the treatment means. The data recorded up to harvest were analyzed as single factor (nitrogen) experiment in RCBD with four replications. The mean values of different characters for all treatments were calculated and the analysis of variance for all the characters under study was performed by the F (variance ratio) test. The mean differences were evaluated by the Least Significant Difference Test as suggested by Gomez and Gomez, (1984).

\section{RESULTS AND DISCUSSION:}

The experiment was conducted to investigate the influence of different levels of nitrogen on the growth and yield of kangkong (Ipomoea reptans poir). The different growth parameters of kangkong analyzed statistically and the results have been presented in Table 1 to Table 8 and Fig 1 to Fig 4 under the following headings.

\section{Effects of nitrogen on growth and yield of Kang- kong}

Effect of Nitrogen on Plant height (cm) - The different doses of nitrogen application had a marked influence on plant height of kangkong at different stages of growth i.e. 15, 30, 45, and 60 days after sowing. The plant height was found to be increased significantly with the increase in nitrogen level up to 100 $\mathrm{kg} / \mathrm{ha}$ (Table 1). At 60 DAS the maximum plant height UniversePG I www.universepg.com
$(67.29 \mathrm{~cm})$ was observed in $\mathrm{T}_{3}$ treatment. In general, plant height increased gradually in the early stages. The minimum plant height $(44.25 \mathrm{~cm})$ was recorded in the control plot $\left(\mathrm{T}_{0}\right)$ at 60 days after sowing. Similar results were found in lettuce and brinjal by Karacal and Turetken, (1972) and Sharmin and Rahman, (2019) findings.

Effect of Nitrogen on number of leaves per plant The application of nitrogen significantly increases the number of leaves per plant (Table 2) on different days after sowing. The highest (56.41) number of leaves was observed in T3 at 60 DAS which was statistically identical with N2 (54.25). The lowest (51.50) number of leaves found in T0 treatment which was statistically different from T1 (53.83). From the observation, it was found that with increasing level of nitrogen application number of leaves increased.

Effect of nitrogen on number of branches per plant - The application of nitrogen significantly increases the production of branches per plant (Table 3) at different stages of growth. At 60 DAS the highest (8.88) number of branches were observed in $\mathrm{T}_{3}$ which was not statistically significant with $T_{2}$ (8.25). The lowest (4.50) number of branches found from the $T_{0}$ treatment. From the observation, it was found that with increasing level of nitrogen application the number of branches was increased. This results in agreement with that of Islam et al. (1984).

Effect of nitrogen on fresh weight per plant (g) - At the first harvest (35 DAS), the maximum $(14.00 \mathrm{~g})$ fresh weight was recorded from $\mathrm{T}_{3}$ treatment which was followed by $\mathrm{T}_{2}(13.16 \mathrm{~g})$ and $\mathrm{T}_{1}(13.08 \mathrm{~g})$ while the minimum (11.75 g) was observed in $\mathrm{T}_{0}$ (control) treatment. On the other hand at the second harvest (60 DAS), the maximum (20 g) fresh weight was found in $\mathrm{T}_{3}$ and the minimum (18.66 g) observed in the control treatment where no nitrogen was applied (Table 4). The present findings either partially or fully agree with the previous works of El-Hassan, (1990) and Kowalska, (1997). Nitrogen promotes vegetative growth which ultimately increases the yield.

Effect of nitrogen on the dry weight of plant (g) - At first harvest (35 DAS), the maximum $(14.00 \mathrm{~g})$ dry weight of foliage was recorded from $\mathrm{T}_{3}$ treatment which was followed by $\mathrm{T}_{2}(13.16 \mathrm{~g})$ and $\mathrm{T}_{1}(13.08 \mathrm{~g})$ 
while the minimum (11.75 g) was observed in $\mathrm{T}_{0}$ (control) treatment. On the other hand, at the second harvest (60 DAS), the maximum (20 g) dry weight was found in $\mathrm{T}_{3}$ and the minimum (18.66 $\mathrm{g}$ ) observed in the control treatment where no nitrogen was applied (Table 5). The possible reason regarding the high dry weight of the plant is that proper dose of nitrogen uptake other nutrients in balance condition which accumulated more plant nutrient that gave more dry matter in the plant.
Effect of nitrogen on root length $(\mathrm{cm})$ of plant Different doses of nitrogen fertilizer also significantly influenced on root length of the plant. The highest root length after harvesting was recorded from $\mathrm{T}_{3}(26.87$ $\mathrm{cm})$ and the lowest root length was recorded in $\mathrm{T}_{0}(20$. $51 \mathrm{~cm})$ control treatment which implies increasing trend of nitrogen fertilizer has a positive effect on root length (Shahen et al., 2019) and for that may be maximum yield was also found in the same treatment $\mathrm{T}_{3}$.

Table 1: Effect of nitrogen on plant height $(\mathrm{cm})$ at different days after sowing.

\begin{tabular}{|c|c|c|c|c|}
\hline Treatment & $\mathbf{1}^{\text {st }}(\mathbf{1 5} \mathbf{D A S})$ & $\mathbf{2}^{\text {nd }}(\mathbf{3 0} \mathbf{D A S})$ & $\mathbf{3}^{\text {rd }}(\mathbf{4 5} \mathbf{D A S})$ & $\mathbf{4}^{\text {th }}(\mathbf{6 0}$ DAS $)$ \\
\hline $\mathrm{T}_{0}$ & $9.86 \mathrm{c}$ & $25.86 \mathrm{~b}$ & $32.25 \mathrm{c}$ & $44.25 \mathrm{c}$ \\
\hline $\mathrm{T}_{1}$ & $12.25 \mathrm{~b}$ & $30.63 \mathrm{ab}$ & $43.63 \mathrm{~b}$ & $56.13 \mathrm{~b}$ \\
\hline $\mathrm{T}_{2}$ & $13.63 \mathrm{ab}$ & $34.38 \mathrm{a}$ & $47.38 \mathrm{a}$ & $64.75 \mathrm{a}$ \\
\hline $\mathrm{T}_{3}$ & $14.75 \mathrm{a}$ & $35.64 \mathrm{a}$ & $50.50 \mathrm{a}$ & $67.28 \mathrm{a}$ \\
\hline LSD(0.05) & $\mathbf{1 . 5 2}$ & $\mathbf{5 . 4 9}$ & $\mathbf{3 . 2 9}$ & $\mathbf{7 . 6 3}$ \\
\hline CV\% & $\mathbf{5 . 4 4}$ & $\mathbf{7 . 8 6}$ & $\mathbf{3 . 4 4}$ & $\mathbf{5 . 9 4}$ \\
\hline
\end{tabular}

*DAS= Day after sowing

Table 2: Effect of nitrogen on the number of leaves per plant at different days after sowing.

\begin{tabular}{|c|c|c|c|c|}
\hline Treatment & $\mathbf{1}^{\text {st }}(\mathbf{1 5} \mathbf{D A S})$ & $\mathbf{2}^{\text {nd }}(\mathbf{3 0} \mathbf{D A S})$ & $\mathbf{3}^{\text {rd }}(\mathbf{4 5} \mathbf{D A S})$ & $\mathbf{4}^{\text {th }}(\mathbf{6 0} \mathbf{D A S})$ \\
\hline $\mathrm{T}_{0}$ & $7.25 \mathrm{~d}$ & $29.25 \mathrm{~d}$ & $36.24 \mathrm{~d}$ & $58.75 \mathrm{~d}$ \\
\hline $\mathrm{T}_{1}$ & $9.50 \mathrm{c}$ & $36.23 \mathrm{c}$ & $50.01 \mathrm{c}$ & $71.69 \mathrm{c}$ \\
\hline $\mathrm{T}_{2}$ & $10.75 \mathrm{~b}$ & $40.26 \mathrm{~b}$ & $55.20 \mathrm{~b}$ & $83.49 \mathrm{~b}$ \\
\hline $\mathrm{T}_{3}$ & $12.51 \mathrm{a}$ & $45.75 \mathrm{a}$ & $62.25 \mathrm{a}$ & $86.81 \mathrm{a}$ \\
\hline LSD(0.05) & $\mathbf{1 . 5 6}$ & $\mathbf{5 . 6 4}$ & $\mathbf{6 . 6 7}$ & $\mathbf{4 . 2 7}$ \\
\hline CV\% & $\mathbf{7 . 0 7}$ & $\mathbf{6 . 7 5}$ & $\mathbf{5 . 9 1}$ & $\mathbf{2 . 5 7}$ \\
\hline
\end{tabular}

Table 3: Effect of nitrogen on the number of branches per plant at different days after sowing.

\begin{tabular}{|c|c|c|c|c|}
\hline Treatment & 1st (15 DAS) & 2nd (30 DAS) & 3rd (45 DAS) & 4th (60 DAS) \\
\hline $\mathrm{T}_{0}$ & 0.00 & $2.35 \mathrm{c}$ & $2.75 \mathrm{~d}$ & $4.50 \mathrm{c}$ \\
\hline $\mathrm{T}_{1}$ & 0.00 & $3.33 \mathrm{~b}$ & $4.98 \mathrm{c}$ & $7.08 \mathrm{~b}$ \\
\hline $\mathrm{T}_{2}$ & 0.00 & $3.85 \mathrm{ab}$ & $5.63 \mathrm{~b}$ & $8.25 \mathrm{ab}$ \\
\hline $\mathrm{T}_{3}$ & 0.00 & $4.05 \mathrm{a}$ & $6.15 \mathrm{a}$ & $8.88 \mathrm{a}$ \\
\hline LSD(0.05) & $\mathbf{0 . 0 0}$ & $\mathbf{0 . 5 6}$ & $\mathbf{0 . 4 8}$ & $\mathbf{1 . 5 6}$ \\
\hline CV\% & $\mathbf{0 . 0 0}$ & $\mathbf{7 . 7 8}$ & $\mathbf{4 . 4 8}$ & $\mathbf{9 . 8 4}$ \\
\hline
\end{tabular}

Effect of nitrogen on fresh and dry weight (g) of root - The maximum fresh weight of root $(11.13 \mathrm{~g})$ was recorded in $T_{3}$ treatment and the minimum fresh weight of root $(6.01 \mathrm{~g})$ was observed in control $\left(\mathrm{T}_{0}\right)$ treatment. On the other hand, the maximum dry weight of root $(0.18 \mathrm{~g})$ was recorded in $\mathrm{T}_{3}$ treatment and the minimum dry weight of root was $(0.11 \mathrm{~g})$ recorded in $\mathrm{T}_{0}$ treatment.

UniversePG I www.universepg.com
Table 4: Effect of nitrogen on the fresh weight $(\mathrm{g})$ of the plant at different days after sowing.

\begin{tabular}{|c|c|c|}
\hline Treatment & $\mathbf{1}^{\text {st }}$ harvest (35 DAS) & $\mathbf{2}^{\text {nd }}$ harvest (60 DAS) \\
\hline $\mathrm{T}_{0}$ & $38.26 \mathrm{~d}$ & $76.66 \mathrm{c}$ \\
\hline $\mathrm{T}_{1}$ & $52.17 \mathrm{c}$ & $107.59 \mathrm{~b}$ \\
\hline $\mathrm{T}_{2}$ & $53.50 \mathrm{~b}$ & $115.51 \mathrm{a}$ \\
\hline $\mathrm{T}_{3}$ & $61.66 \mathrm{a}$ & $116.54 \mathrm{a}$ \\
\hline $\mathbf{L S D}(\mathbf{0 . 0 5})$ & $\mathbf{1 . 2 1}$ & $\mathbf{0 . 7 6}$ \\
\hline $\mathbf{C V \%}$ & $\mathbf{1 . 4 8}$ & $\mathbf{0 . 4 6}$ \\
\hline
\end{tabular}


Table 5: Effect of nitrogen on the dry weight of plant (g) at different days after sowing.

\begin{tabular}{|c|c|c|}
\hline Treatment & 1st (35 DAS) & 2nd (60 DAS) \\
\hline $\mathrm{T}_{0}$ & $7.36 \mathrm{~d}$ & $15.11 \mathrm{c}$ \\
\hline $\mathrm{T}_{1}$ & $10.14 \mathrm{c}$ & $18.20 \mathrm{~b}$ \\
\hline $\mathrm{T}_{2}$ & $10.74 \mathrm{~b}$ & $19.92 \mathrm{a}$ \\
\hline $\mathrm{T}_{3}$ & $11.87 \mathrm{a}$ & $20.48 \mathrm{a}$ \\
\hline LSD(0.05) & $\mathbf{0 . 4 6}$ & $\mathbf{0 . 8 5}$ \\
\hline CV\% & $\mathbf{2 . 0 9}$ & $\mathbf{2 . 1 9}$ \\
\hline
\end{tabular}

Table 6: Effect of nitrogen on root length $(\mathrm{cm})$ at different days after sowing.

\begin{tabular}{|c|c|}
\hline Treatment & Root Length 60 DAS (cm) \\
\hline $\mathrm{T}_{0}$ & $20.51 \mathrm{~d}$ \\
\hline $\mathrm{T}_{1}$ & $25.19 \mathrm{c}$ \\
\hline $\mathrm{T}_{2}$ & $26.24 \mathrm{~b}$ \\
\hline $\mathrm{T}_{3}$ & $26.87 \mathrm{a}$ \\
\hline LSD(0.05) & $\mathbf{0 . 4 6}$ \\
\hline CV\% & $\mathbf{1 . 1 9}$ \\
\hline
\end{tabular}

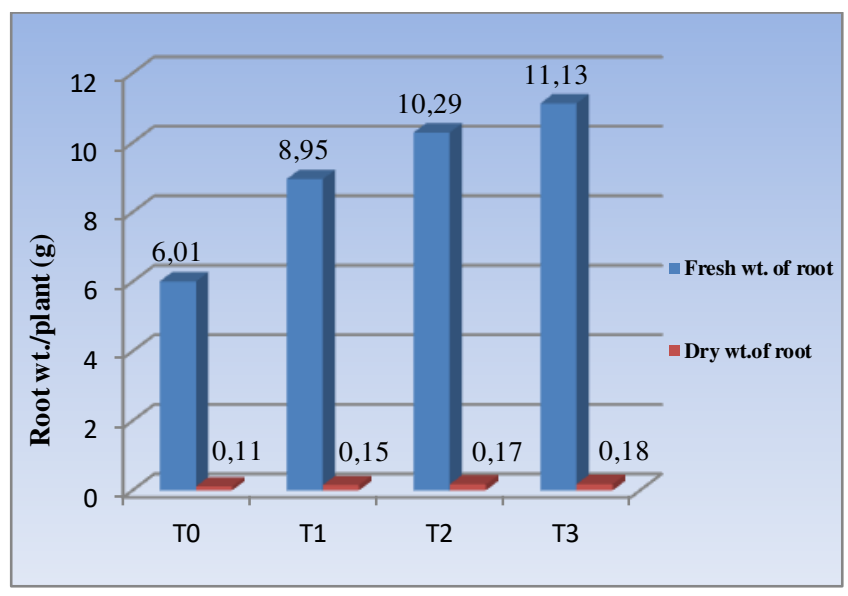

Fig 2: Effect of nitrogen on fresh and dry wt. of root (g) at different days after sowing.

The fresh weight of root 60 days after harvesting was $(6.01 \mathrm{~g}),(8.95 \mathrm{~g}),(10.29 \mathrm{~g})$, and (11.13 g) per plant, and dry weight of root was $(0.11 \mathrm{~g}),(0.15 \mathrm{~g}),(0.17 \mathrm{~g})$, and $(0.18 \mathrm{~g})$ per plant recorded in $\mathrm{T}_{3}, \mathrm{~T}_{2}, \mathrm{~T}_{1}$, and $\mathrm{T}_{0}$ treatment respectively (Fig 2).

Effect of nitrogen on yield per plot (g) - The different doses of nitrogen application influenced the yield/ plot of Kangkong (Table 6). At the first harvest (35 DAS) the maximum yield (786.84 g) was obtained from $\mathrm{T}_{3}$ treatment and the minimum yield (480.53 g) was obtained from the control treatment $\left(\mathrm{T}_{\mathrm{O}}\right)$. At 60 DAS the yield range of the present study varied from 1786.90 to $1182.50 \mathrm{~g}$. The maximum yield (1786.90 g) UniversePG I www.universepg.com was observed from the $T_{3}$ treatment and the lowest $(1182.50 \mathrm{~g})$ was recorded from the control treatment $\left(\mathrm{T}_{0}\right)$. The possible reason for such yield due to an increase in the nitrogen doses because nitrogen possess vegetative growth which results in a better yield.

Table 7: Effect of nitrogen on yield (gm/plant) at different days after sowing.

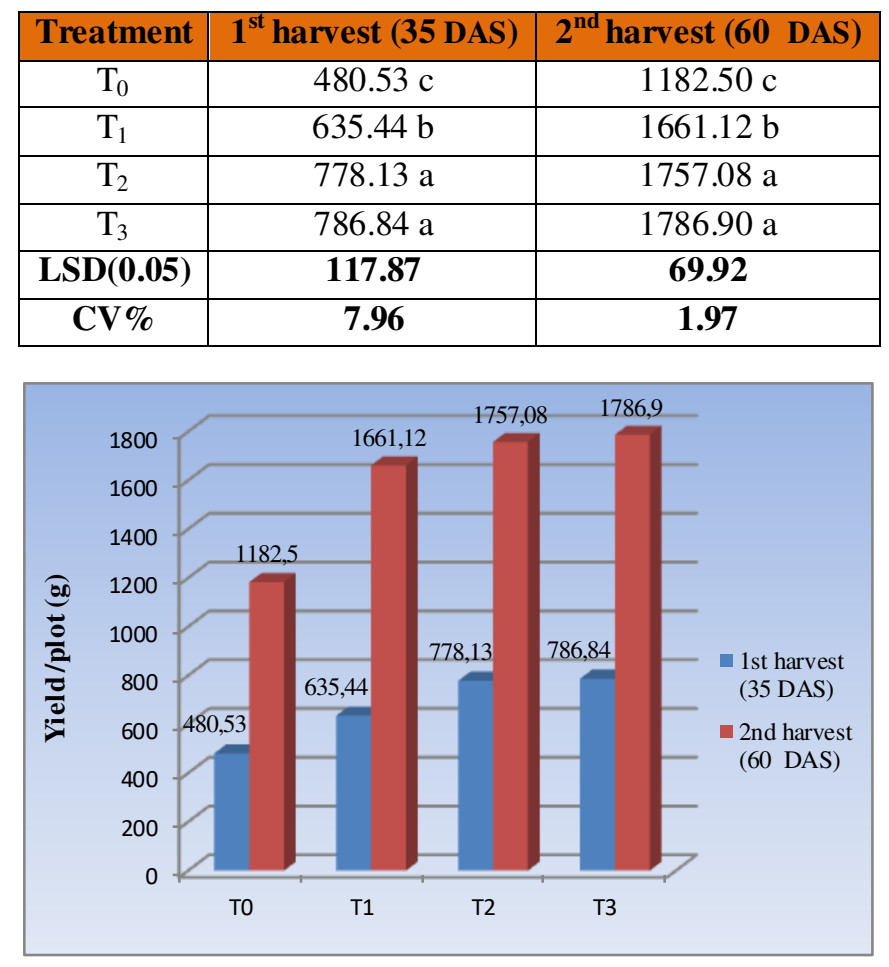

Fig 3: Effect of nitrogen on yield per plot (g) at different days after sowing.

Effect of nitrogen on yield (ton/hac) of KangKong The different doses of nitrogen application influenced the yield per ha (t) of kangkong (Table 7). At the first harvest (35 DAS) the maximum yield per ha (7.87 t/ha) was observed from $\mathrm{T}_{3}$ treatment and the minimum yield per ha (4.81 t/ha) was observed in the control treatment $\left(\mathrm{T}_{0}\right)$. At $60 \mathrm{DAS}$ the yield range of the present study varied from 17.87 to $11.83(\mathrm{t} / \mathrm{ha})$, the maximum (17.87 t/ha) gross yield was observed from $\mathrm{T}_{3}$ treatment which was statistically identical with $\mathrm{T}_{2}$ and the lowest $(11.83 \mathrm{t} / \mathrm{ha})$ was observed from the control treatment $\left(\mathrm{T}_{0}\right)$. The possible reason for such yield due to an increase in the nitrogen dose because nitrogen posses vegetative growth which results in a better yield. Bruemmer and Roe, (1979) reported that nitrogen had a positive effect to increase the yield of water spinach (I. aquatica). A similar observation was also found Sharmin and Rahman, (2019) published report. 
Table 8: Effect of nitrogen on yield ton/hac at differrent days after sowing.

\begin{tabular}{|c|c|c|}
\hline Treatment & $\mathbf{1}^{\text {st }}$ harvest (35 DAS) & $2^{\text {nd }}$ harvest (60 DAS) \\
\hline T0 & $4.81 \mathrm{c}$ & $11.83 \mathrm{c}$ \\
\hline $\mathrm{T} 1$ & $6.35 \mathrm{~b}$ & $16.61 \mathrm{~b}$ \\
\hline $\mathrm{T} 2$ & $7.78 \mathrm{a}$ & $17.57 \mathrm{a}$ \\
\hline $\mathrm{T} 3$ & $7.87 \mathrm{a}$ & $17.87 \mathrm{a}$ \\
\hline LSD(0.05) & $\mathbf{1 1 7 . 8 7}$ & $\mathbf{6 9 . 9 2}$ \\
\hline CV\% & $\mathbf{7 . 9 6}$ & $\mathbf{1 . 9 7}$ \\
\hline
\end{tabular}

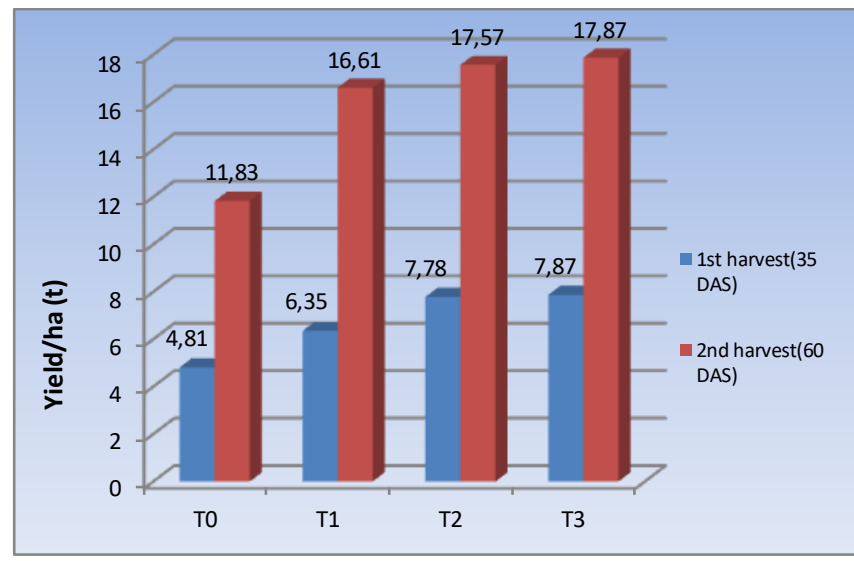

Fig 4: Effect of nitrogen on yield (ton/hac) at different days after sowing.

\section{CONCLUSION:}

Based on the result of the present study it was found that nitrogen enhances vegetative growth. Leafy vegetable production was increasing with an increase in nitrogen dose. It was observed that $\mathrm{T}_{3}$ plants were looking fresher and gave higher production than three other treatments (Islam et al., 2021). Though the maximum height of the plant, leaves, branches, was in T3 and the root length was more in $\mathrm{T}_{3}$. The maximum production was observed in $\mathrm{T}_{3}(1786.90 \mathrm{gm})$ and the minimum production was observed in $\mathrm{T}_{0}(1182.50)$, where no fertilizer was used. Considering the plant height, leaf number, branch number, root length, root weight, total production, it is revealed from the study that the Kangkong can grow successfully and efficiently under the treatment of $\mathrm{T}_{3}$, where $100 \mathrm{~kg}$ nitrogen/hectare were used. The study finally concluded that before the final optimization of the application dose, further study is needed in different seasons and agro-ecological zones of Bangladesh.

\section{ACKNOWLEDGMENT:}

The authors would like to express their gratitude to the College of Agricultural Sciences of International University of Business Agriculture and Technology, Dhaka, UniversePG I www.universepg.com
Bangladesh for the cooperation to conduct the research work.

\section{CONFLICTS OF INTEREST:}

The authors declared there are no conflicts of interest in publishing the research work.

\section{REFERENCES:}

1) Anonymous, (1983). Influence of different basal dose and top dressing of urea on the yield of Gimakalmi. In: Annual Report, CVSRC, BARI, Joydebpur, Gazipur. pp. 34-36.

2) Bruemmer, J.H. and B. Roe. (1979). Effect of nitrogenous fertilizer on the yield and chemical composition of water spinach (Ipomoea aquatia). Proc. Florida Hort. Soci. 140-143.

3) El-Hassan, E. A. A. (1990). Yield and nitrate content of lettuce in relation to some cultural practices. Bulletin of Faculty of Agriculture, University of Cairo. 41(2): 407-417.

https://www.cabdirect.org/cabdirect/abstract/19920 $\underline{313149}$

4) Gomez, K.H. and A. A. Gomez. (1984). Statistical Procedures for Agricultural Research. Second Edn. Wiley-Inter Science publication, John Wiley and Sono. New York, p. 680. https://pdf.usaid.gov/pdf_docs/PNAAR208.pdf

5) Hossain. M.M. and M.A. Siddique. (1982). Effect of plant density on the yield of two cultivars of kangkong. Bangladesh. J. Agri. Sci., 9(2): 241-244.

6) Hossain, M.Z. (1990). Effects of nitrogen and suplhur on growth, yield and nutrient content of rice. M.Sc. thesis, Dept. of Soil Science, Bangladesh Agricultural University, Mymensingh. Pp. 17.

7) Islam, A. B. M. Z, M. A. Siddique and M. M. Hossain, (1984). The influence of planting material and dose of nitrogen on the yield of kangkong (Ipomoea aquatica). Thai. J. Agric. Sci., 17(2): 81-87.

8) Islam MN, Sharmin S, and Rahman MA. (2021). Effects of different biofertilizer on soybean (Glycine max) production. Am. J. Pure Appl. Sci., 3(3), 55-59.

https://doi.org/10.34104/ajpab.021.055059

9) Karacal, I and I. Turetken. (1972). Effect of application of increasing rates of ammonium 
sulophate fertilizer on yield and nutrient uptake in the lettuce plant. Yuzuncu-Yil-Univ. Turkey, 2(2): 95-106.

10) Karim MR, Islam M, Bhuiyan MSH, and Mian JA. (2021). Potassium fractions and rice yield in different agro-ecological zones of Bangladesh. Am. J. Pure Appl. Sci., 3(2), 35-41. https://doi.org/10.34104/ajpab.021.035041

11) Kowalska, I. (1997). Effects of urea-ammonium, and nitrate nitrogen on the yield and quality of greenhouse lettuce grown on different media. Folia Horticulture, 9(2): 31-40.

https://agris.fao.org/agris-search/search.do?recordI $\mathrm{D}=\mathrm{PL1998000362}$

12) Li, X.; Liu, Z.Z.; Ji, W.W. (2019). Effects of nitrogen application on osmotic regulators in leaves of different plant types of rice. Jiangsu Agric. Sci., 47, 117-121.

https://doi.org/10.21203/rs.2.13307/v1

13) Qamar Z. U, Hamid F, S, Fayaz A, and Navid A. (2018). Impact of Various Levels of Nitro-gen and Phosphorus on Growth and Yield of Spinach (Spinacea oleracea L.) under Conditions of Mansehra (Pakistan). Open Academic Journal of Advanced Science and Technology, 2(1): 5-8 https://doi.org/10.33094/5.2017.2018.21.5.8

14) Rashid, M.A., M.S. Ahmad, M.A. Hussain and A.M.M.A. Hussain. (1985). Gimakalmi-a new leafy vegetable for rainy season of Bang-ladesh. Bangladesh Hort., 13(1-2):79-81.

15) Shahen MZ, Uddin ME, and Alam MS. (2019). Effect of antibiotic susceptibility and inhibitory activity for the control of growth and survival of microorganisms of extracts of C. officinalis. Eur. J. Med. Health Sci., 1(3), 1-9. https://doi.org/10.34104/ejmhs.0190109

16) Sharmin S. and Rahman L. (2019). Optimization of nitrogen requirement for better growth and yield of Brinjal (Solanum melongena L. Archives of Agriculture and Environmental Science. 4(1):33-38 https://doi.org/10.26832/24566632.2019.040105

17) Shinohara, S. (1978). Production prospects of short period leafy vegetables of South East Asia during rainy season in Bangladesh. Central Extension Resources Development Institute, Joydebpur, Gazipur. 36-38.

18) Shinohara, S. (1980). Book for Development of Vegetable Horticulture with Capable Seed Production in Bangladesh. Central Extension Resources Development Institute, Joydebpur, Gazipur, Pp. 218.

19) Stiller V, Lafitte H. R, Sperry J. S. (2003). Hydraulic properties of rice and the response of gas exchange to water stress. Plant Physiol, 132: 1698-1706. https://doi.org/10.1104/pp.102.019851

Citation: Sharmin S, Parvin R, and Habiba U. (2021). Response of different doses of nitrogen fertilizer on growth and yield of KangKong (Ipomoea reptans poir). Am. J. Pure Appl. Sci., 3(4), 98-105.

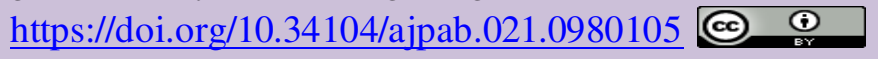

